\title{
Synthesis and Photoregulated Metal Coordination of Azobenzene Polymer Having Ion Binding Sites
}

\author{
Masato Nanasawa, ${ }^{*}$ Takahiro Nishiyama, and Hiroyoshi Kamogawa \\ Department of Applied Chemistry and Biotechnology, Faculty of Engineering, \\ Yamanashi University, Kofu 400, Japan
}

(Received July 3, 1990)

\begin{abstract}
Vinyl polymers having pendant $3,3^{\prime}$-substituted azobenzene were synthesized. Selective metal extracting ability was found in the photoisomerized polymers having bisiminodiacetic acid groups. The selectivity was large in the azobenzene with directly connected imino-groups rather than those having the methylene chain spacers between the rings and imino-groups. The metal coordination was not strong, so that the complexed cis-isomer thermally recovered to the trans one. The reversible transformation suggests possible applications for photoregulated macromolecular ionophores.

KEY WORDS Azobenzene Polymer/Photoisomerization/Metal Extraction / Photoregulated Macromolecular Ionophore /
\end{abstract}

Azobenzene and many of its derivatives exhibit large confomational change by reversible trans-cis transformation. A number of polymers having azobenzene moieties have been synthesized and their photo-induced isomerization has received much attention for functions as photoresponsive polymer, including the change of viscosity, $\mathrm{pH}$, conductivity, solubility, wettability, and mechanical properties. ${ }^{1}$ Recently some azobenzene derivatives having two iminodiacetic acid groups ${ }^{2,3}$ and a variety of crown ethers ${ }^{4}$ at both $4,4^{\prime}$-position have been synthesized to mimic the behavior of reversible ion binding affinity in biological systems; their ion binding properties have been controlled by photo-induced trans-cis isomerization.

The authors have been interested in the synthesis of vinyl polymers having azobenzene moieteis with ionic metal binding sites and the behavior of their metal extracting ability. The rate of isomerization is reduced if a substituent group at 2- and/or 4-position would contribute to the resonance stabilization of azidostructure $^{5}$ and if a proton donating groups at 2-position would make hydrogen bonds with adjacent azo-group. ${ }^{5,6}$ In order to enhance the reversible trans-cis transformation, metal binding ligands are connected at the 3-position of both phenyl rings in spite of two substituent groups existing in anti- and syn-configuration on azobenzene rings. The distance between two carbons at 3,3'-position of non planar cisisomer is below $5 \AA$. $^{7}$ Therefore two substituent groups become feasible to interact each other compared with those in trans-isomer and $4,4^{\prime}$-ones in cis-azobenzene. However, two ligands in the cis-isomer should moderately bind with metal ions, because the very stable complex stabilizes the cis-form and can not release the ion efficiently on the reverse transformation. We thus synthesized low molecular weight compounds designed by a space filling molecular model, in which for the cis-isomer the negatively charged oxygen ligands could be brought close to metal ions enough to bind intramoleclarly. However, this binding is not possible or much weaker in the planar trans-form.

The low molecular weight azo-compounds 
synthesized were isomerized in an aqueous solution with or without metal ions in order to estimate the spatial fitness between the two ligands and metal ions. The compounds bearing two ligands, which may interact with metal ions, were transformed to vinyl azobenzenes; metal extracting efficiencies of the resulting polymers were investigated.

\section{RESULTS AND DISCUSSION}

Synthesis of Azobenzene Derivatives and the Effect of Metal on Their Isomerization

Azobenzene derivatives having ion binding sites were synthesized, in which the 3,3'-ligands could be close to the metal ionic radius; these were designed as analogues of salicyclic acid, malonic acid, ethylenedihydroxamic acid, dimethylglyoxime, and ethylenediaminetetraacetic acid. The structures and symbols of compounds synthesized are shown in Table I. The best known method of preparing aromatic azocompounds involves coupling of diazonium salts with reactive aromatic compounds, while the method is not applicable to the preparation of 3,3'-disubstituted azobenzenes. An unsymmetrical compound in which different substituent groups connect to the aromatic ring was synthesized by condensation of a C-nitroso compound with an aniline derivative, and symmetrical ones were synthesized by the bimolecular reduction of nitrobenzene derivatives. The mobility of $3,3^{\prime}$-ligands is restricted on the rigid azobenzene, especially when the proton-donating ligands connect directly to the ring as in compounds I and II. However, if there were some interactions between two ligands in the cis-isomer and metal ions, the rate of isomerization would be certainly influenced by the interaction: the rate of photo-isomerization would be accelerated by the formation of complexes, while the reverse reaction would be suppressed due to the need to break the coordinate bond. The rate of isomerization with added metal ions was thus measured in order to estimate the cooperative interaction.

Photoisomerization reaches a stationary state within a couple of minutes and pseudo first order constants are small in the case of

Table I. Pseudo first order rate constants for isomerization

\begin{tabular}{|c|c|c|c|c|c|c|c|c|}
\hline \multirow{2}{*}{ No. } & \multicolumn{2}{|c|}{ Azocompound } & \multicolumn{2}{|c|}{ trans to $c i s^{\mathbf{a}}$} & \multicolumn{4}{|c|}{ cis to $\operatorname{trans}^{\mathrm{b}}$} \\
\hline & $3-$ & $3^{\prime}-$ & $\begin{array}{l}\text { No } \\
\text { metal }\end{array}$ & $\mathrm{Zn}$ & $\begin{array}{l}\text { No } \\
\text { metal }\end{array}$ & $\mathrm{Cu}$ & $\mathrm{Zn}$ & Co \\
\hline I & $-\mathrm{OH}$ & $-\mathrm{COOH}$ & 1.3 & 0.99 & 9.2 & 8.4 & 6.1 & 7.0 \\
\hline II & $-\mathrm{COOH}$ & $-\mathrm{COOH}$ & 1.2 & 1.0 & 8.4 & 9.2 & 7.8 & 8.3 \\
\hline III & $\begin{array}{l}-\mathrm{CNHOH} \\
\stackrel{\mathrm{O}}{ }\end{array}$ & $\begin{array}{l}\mathrm{CNHOH} \\
\stackrel{\mathrm{O}}{ }\end{array}$ & 1.0 & $-c)$ & - & - & - & \\
\hline IV & $-\mathrm{CH}=\mathrm{NOH}$ & $-\mathrm{CH}=\mathrm{NOH}^{\mathrm{d}}$ & 1.2 & 0.52 & 7.8 & 10.2 & 7.5 & 7.8 \\
\hline $\mathrm{V}$ & $-\mathrm{N}\left(\mathrm{CH}_{2} \mathrm{COOH}\right)_{2}$ & $-\mathrm{N}\left(\mathrm{CH}_{2} \mathrm{COOH}\right)_{2}$ & 0.69 & 0.80 & 7.5 & 8.9 & 4.3 & 6.6 \\
\hline VI & $\begin{array}{l}-\mathrm{NCH}_{2} \mathrm{COOH} \\
\stackrel{\mathrm{l}}{\mathrm{C}} \mathrm{H}_{2} \mathrm{CONHBu}\end{array}$ & $-\mathrm{N}\left(\mathrm{CH}_{2} \mathrm{COOH}\right)_{2}$ & 0.65 & 0.77 & 6.3 & 7.5 & 2.5 & 5.5 \\
\hline VII & $\begin{array}{l}-\mathrm{NCH}_{2} \mathrm{COOH} \\
\stackrel{\mathrm{I}}{\mathrm{C}} \mathrm{H}_{2} \mathrm{CONHBu}\end{array}$ & $\begin{array}{c}-\mathrm{NCH}_{2} \mathrm{COOH} \\
\stackrel{\mathrm{I}}{\mathrm{C}} \mathrm{H}_{2} \mathrm{CONHBu}\end{array}$ & 0.60 & 0.57 & 6.4 & 7.8 & 4.6 & 5.5 \\
\hline IIX & $-\mathrm{CH}_{2} \mathrm{~N}\left(\mathrm{CH}_{2} \mathrm{COOH}\right)_{2}$ & $-\mathrm{CH}_{2} \mathrm{~N}\left(\mathrm{CH}_{2} \mathrm{COOH}\right)_{2}$ & 0.66 & 0.66 & 7.3 & 8.6 & 2.9 & 4.3 \\
\hline IX & $\begin{array}{r}-\mathrm{CH}_{2} \mathrm{NCH}_{2} \mathrm{COOH} \\
\quad \mathrm{CH}_{2} \mathrm{CONHPh}\end{array}$ & $-\mathrm{CH}_{2} \mathrm{~N}\left(\mathrm{CH}_{2} \mathrm{COOH}\right)_{2}$ & 0.51 & 0.54 & 7.7 & 11.0 & 5.6 & 7.1 \\
\hline
\end{tabular}

Azocompound, $1.25 \times 10^{-4} \mathrm{~mol}^{-1}$ in water containing 1.2 equivalent metal hydroxide. ${ }^{\text {a }} 10^{2} \mathrm{k} \mathrm{s}^{-1}$ at $25^{\circ} \mathrm{C}$. b $10^{2} \mathrm{k} \mathrm{h}^{-1}$ at $45^{\circ} \mathrm{C}^{\mathrm{c}}$ precipitate formed. $^{\mathrm{d}}$ in aq $10 \%$ ethanol. 
azobenzene having large molecular weight substitutions. The effect of metal addition on the rate of photoisomerization could not be determined quantitatively, presumably due to the catalytic effect of metal on the back reaction, ${ }^{8,9}$ and each ligand might act independently to form intermolecular $2: 1$ or $1: 1$ metal/trans-isomer complexes to some extent. ${ }^{10}$ The resulting coordination in the trans-isomer might inhibit the photoisomerization. Especially in the case of trans-III, a strong metal complexability of the hydroxamic acid group $^{10}$ induces the precipitation of intermolecular complexes in an aqueous solution.

The degree of thermal isomerization of IIX is $8 \%$ at $25^{\circ} \mathrm{C}$ for $17 \mathrm{~h}, 40 \%$ at $50^{\circ} \mathrm{C}$ for $3 \mathrm{~h}$, and $60 \%$ at $60^{\circ} \mathrm{C}$ for $1 \mathrm{~h}$; these values are large compared with that of the 4,4'-disubstituted one. ${ }^{2,3}$ When the effect of metal addition on the rate was compared to that of azobenzene alone at $45^{\circ} \mathrm{C}$, there was little difference in II and IV. Compound-II was simulated to dibasic acids such like malonic acid, which coordinates $1: 1$ - or $1: 2$-complex, and its stability constant with metals is over $10^{4} .{ }^{12}$ Two ligands directly connected to the rigid azobenzene ring in II are difficult to bind metal ions cooperatively; compound-IV might also not be present as anti-imino-conformation like dimethylglyoxime. ${ }^{12}$ The inhibitory effect on thermal isomerization was observed for azobenzene having the hydroxy-carboxy combination and bisiminodiacetic acid groups. The interaction between two ligands and metal ion is not strong, so that the $c i$ s-isomers almost transform to the trans-ones within $12 \mathrm{~h}$ at $45^{\circ} \mathrm{C}$.

\section{Synthesis of Azobenzene Polymer and Its Metal} Extracting Efficiency

Vinyl polymers having a pendant azobenzene moiety exhibiting some interaction with metal ions were synthesized as follows.

A coupling reaction of $m$-nitrosophenol with 3,5-diaminobenzoic acid did not give 3-amino5 -(hydroxyphenylazo)benzoic acid in a sufficient yield compared with the synthesis of I,

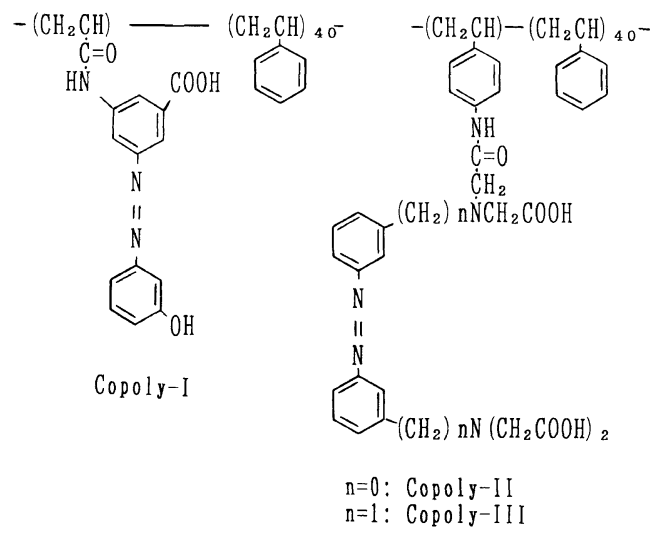

and produced a large amount of unknown black precipitate. Therefore, after the isolation of the precipitate, the filtrate was acylated with acryl chloride without purification, and the reaction mixture was subjected to column chromatography. Dicyclohexylcarbodiimide (DCC)-urea appeared in the reaction mixture of DCC and bis(carboxymethyl)iminoazobenzene derivatives ( $\mathrm{V}$ and IIX) in dimethylacetamide (DMAc). An acyl-isourea produced as intermediate reacts with the remaining carboxyl group in iminodiacetic acid to form anhydride, the resulting anhydride being condensed with $p$-aminostyrene after the isolation of DCC-urea. Vinyl monomers were copolymerized with styrene in a sealed glass ampule: the resulting copolymers containing large amounts of styrene units were soluble in benzene, chloroform, and polar aprotic solvents.

Metal extracting efficiencies were evaluated from distribution equilibria of picrate ions between aqueous phase and organic phases. ${ }^{13}$ The transfer of picric acid from the aqueous phase was little for the solution of Copoly-I. The amount of azobenzene unit in the polymer is less than several percent, thereby it is difficult for two pendant azobenzenes to cooperate intermolecularly. Both hydroxy and carboxy groups in the cis-isomer might not act cooperatively on the metal extraction or act weakly compared with picrate anions. This 
Table 2. Metal extracting efficiency of azopolymers ${ }^{\mathrm{a}}$

\begin{tabular}{|c|c|c|c|c|c|c|}
\hline \multirow{3}{*}{$\begin{array}{l}\text { Polymer } \\
\text { Metal ion }\end{array}$} & \multicolumn{2}{|c|}{ Copoly-I } & \multicolumn{2}{|c|}{ Copoly-II } & \multicolumn{2}{|c|}{ Copoly-III } \\
\hline & trans-ext & cis-ext. & trans-ext. & cis-ext. & trans-ext. & cis-ext. \\
\hline & $\% \mathrm{~b}$ & $\%^{\mathrm{c}}$ & $\%$ & $\%$ & $\%$ & $\%$ \\
\hline $\mathrm{Ca}$ (II) & 0.2 & 1.0 & 0.4 & 2.6 & 1.5 & 3.7 \\
\hline $\mathrm{Zn}$ (II) & 2.1 & 4.0 & 3.6 & 25.8 & 5.6 & 23.5 \\
\hline $\mathrm{Cu}$ (II) & 1.2 & 1.4 & 9.8 & 18.5 & 14.3 & 22.7 \\
\hline $\mathrm{Pb}$ (II) & 2.9 & 8.3 & 11.2 & 23.0 & 38.1 & 45.7 \\
\hline
\end{tabular}

a Percentage of pendant cis-azobenzene (cis\%): Copoly-I, 50\%; Copoly-II, 54\%; Copoly-III, 48\%. Aqueous phase: picric acid $\left(10^{-3} \mathrm{~mol}^{-1}\right)$ and metal hydroxide $\left(2.5 \times 10^{-3} \mathrm{moll}^{-1}\right)$; benzene phase: azobenzene unit $\left(10^{-3} \mathrm{~mol} \mathrm{l}^{-1}\right)$.

b Extracted picrate with trans-azobenzene polymer.

c Calculated by the equation, cis-ext. $\%=($ ext. $\%$ with photoisomerized polymer $-\operatorname{trans} \% \times \operatorname{trans}$-ext. $\%) /$ cis $\%$.

suggests that the decrease in the rate of thermal isomerization of low molecular weight azobenzene-I might be cause by $1: 2$-complexation with the metal ion and/or an electron-donating effect of the resulting carboxylate anion on the azo-linkage. ${ }^{4 a}$

When a benzene solution of Copoly-II or -III was vigorously stirred in an aqueous solution of metal picrate, an insoluble polymer complexed with metals appeared in both phases. The metal extracting efficiencies of both trans-and cis-Copoly-III were larger than those of Copoly-II, while the selectivity, an extraction ratio of cis-isomer to trans-one, was in the reverse order. Methyliminodiacetic acid group possesses a relatively higher mobility and stronger basicity for the imino-nitrogen atom than the iminodiacetic acid group. This tends to coordinate the metal ion with the monoligand on one side of the disubstituted azobenzene, and leads to small difference in metal coordination between trans- and cisCopoly-III. The affinity of metal ions for Copoly-II and -III has the same tendency to complex stability against hydoxy anion $\left(K_{\mathrm{OH}}\right),{ }^{14}$ and is especially high in the case of lead ion possessing a large ionic radius. Calcium ion ${ }^{15}$ which plays an important role in a variety of physiological processes was extracted only in a small amount by both copolymers, presumably due to low $K_{\mathrm{OH}}$ and small ionic radius of the calcium ion. Both Copoly-II and -III exhibit high selectivity for zinc ion, the phenomenon being similar to the result of the early work for 4,4'-bis[bis(carboxymethyl)iminomethyl]azobenzene. ${ }^{2}$ Although it is impossible to attain $100 \%$-selectivity, that is, all or nothing change in ion binding ability because of the occurrence of coordination by the mono-iminodiacetic acid group, the amount of immissible cis-azobenzene polymer complexed with metal ions slowly decreases with stirring in the dark, more efficiently by heating. The absorbance of picrate salt in aqueous phase and that of trans-azobenzene in organic phase were the same values as those treated with trans-azobenzene polymers. Although there are many other combinations of ligands which we chose, the results indicate that the strain energy of the ligand connected to the rigid azobenzene induces a moderate bind to metal ions and enables the azobenzene to thermally recover the trans-form. The reversibility suggests possible applications for photoregulated macromolecular ionophores.

\section{EXPERIMENTAL}

Synthesis of 3,3'-Disubstituted Azobenzene

3-Hydroxy-3'-carboxyazobenzene (I): $m$-Ni- 
trosophenol $^{16}(1.23 \mathrm{~g}, 10 \mathrm{mmol})$, prepared from $n$-nitrophenol, was added to a solution of $m$-aminobenzoic acid $(2.74 \mathrm{~g}, 20 \mathrm{mmol})$ in ethanol $(40 \mathrm{ml})$ containing $5 \mathrm{ml}$ of acetic acid. The reaction mixture was stirred at $40^{\circ} \mathrm{C}$ for $4 \mathrm{~h}$ and then poured into water. The brown precipitate was recrystallized from tetrahydrofuran (THF)-toluene (1:9). Yield 50\%; mp $220-223^{\circ} \mathrm{C}$; IR (KBr): $3200(\mathrm{OH}), 1690$ $(\mathrm{COOH}) \mathrm{cm}^{-1} ;{ }^{1} \mathrm{H}$ NMR (dimethylsulfoxide, DMSO- $\left.d_{6}\right), \delta: 7.0(\mathrm{~s}, 1 \mathrm{H}, 4-\mathrm{ArH}), 7.3(\mathrm{~m}, 3 \mathrm{H}$, 2-, 5-, 5'-ArH), 8.0 (m, 3H, 6-, 4'-, 6'-ArH), 8.2 (s, 1H, 2'-ArH), 9.8-10.5 (2H, COOH, OH) ppm; $\quad \alpha_{\max }=318 \mathrm{~nm} ; \quad \varepsilon=150001 \mathrm{~mol}^{-1} \mathrm{~cm}^{-1}$ (ethanol). Found: C, 64.53\%; H, 4.18\%; N, $11.31 \%$. Calcd for $\mathrm{C}_{13} \mathrm{H}_{10} \mathrm{~N}_{2} \mathrm{O}_{3}$ : C, $64.46 \%$; $\mathrm{H}, 4.13 \%$; N, $11.57 \%$.

3,3'-Dicarboxyazobenzene ${ }^{17 a}$ (II): $m$-Nitrobenzoic acid was reductively coupled with zinc powder in $50 \%$ aqueous ethanol containing sodium hydroxide; the product was recrystallized from ethanol. Yield $87 \%$; $\mathrm{mp}$ $228-230^{\circ} \mathrm{C}$ (decomp.); $\alpha_{\max }=320 \mathrm{~nm} ; \varepsilon=$ $140001 \mathrm{~mol}^{-1} \mathrm{~cm}^{-1}$ (ethanol).

3, $3^{\prime}$-Bis $(N$-hydroxycarbamoyl)azobenzene (III): A pyridine solution of 3,3'-bis(benzyloxycarbonyl)azobenzene $(1.36 \mathrm{~g}, 3 \mathrm{mmol})$, prepared from the triethylammonium salt of II with benzyl bromide, was added to a mixture of hydroxylamine $(2.15 \mathrm{~g}, 30 \mathrm{mmol})$ and sodium methoxide $(40 \mathrm{mmol})$ in pyridine $(15 \mathrm{ml})$ at $5^{\circ} \mathrm{C}$ with vigorously stirring. The reaction mixture was stirred at room temperature overnight. The orange solid was isolated, washed with acetone, and then dissolved in dil. sodium hydroxide solution. An insoluble portion was filtered off and the filtrate was acidified. The precipitate was washed with water, and then recrystallized from ethanol. Yield $78 \%$; mp $220-225^{\circ} \mathrm{C}$ (decomp.); IR (KBr): $3300(\mathrm{NH}), 2500-2800(\mathrm{OH}), 1660$ (free $\mathrm{C}=\mathrm{O}$ ), 1620 (intramolecular $\mathrm{H}$-bonding $\mathrm{C}=\mathrm{O}^{11}$ ) $\mathrm{cm}^{-1} ;{ }^{1} \mathrm{H}$ NMR (DMSO- $d_{6}$ ), $\delta$ : $7.8-8.3\left(\mathrm{~m}\right.$, ArH) ppm; $\alpha_{\max }=317 \mathrm{~nm} ; \varepsilon=$ $130001 \mathrm{~mol}^{-1} \mathrm{~cm}^{-1}$ (ethanol). Found: $\mathrm{C}$, $56.21 \% ; \mathrm{H}, 4.12 \% ; \mathrm{N}, 18.24 \%$. Calcd for
$\mathrm{C}_{14} \mathrm{H}_{12} \mathrm{~N}_{4} \mathrm{O}_{4}: \mathrm{C}, \quad 56.00 \% ; \mathrm{H}, \quad 4.00 \% ; \mathrm{N}$, $18.66 \%$.

3,3'-Bis(hydroxyiminomethyl)azobenzene (IV): Diethylacetal of $m$-nitrobenzaldehyde was reductively coupled with zinc powder, followed by hydrolysis to 3,3'-diformylazobenzene, mp $130-132^{\circ} \mathrm{C}$ (lit. ${ }^{17 \mathrm{~b}} 150^{\circ} \mathrm{C}$ ).

3,3'-Diformylazobenzene was condensed with hydroxylamine- $\mathrm{HCl}$ salt in a pyridine-ethanol $(1: 1)$ solution. The product was recrystallized from $50 \%$ aqueous methanol. Yield $72 \%$; mp $178-179^{\circ} \mathrm{C}$; IR (KBr): 3200 (OH), $960(\mathrm{~N}-\mathrm{O}) \mathrm{cm}^{-1} ;{ }^{1} \mathrm{H}$ NMR (DMSO$\left.d_{6}-\mathrm{CDCl}_{3}\right), \delta: 7.7-8.3(\mathrm{~m}, 8 \mathrm{H}, \mathrm{ArH}), 11.4$ (s, 2H, OH) ppm; $\alpha_{\max }=318 \mathrm{~nm} ; \varepsilon=19000$ $1 \mathrm{~mol}^{-1} \mathrm{~cm}^{-1}$ (ethanol). Found: C, $62.60 \%$; $\mathrm{H}, 4.50 \%$; N, 20.74\%. Calcd for $\mathrm{C}_{14} \mathrm{H}_{12} \mathrm{~N}_{4} \mathrm{O}_{2}$ : C, $62.69 \% ; \mathrm{H}, 4.48 \%$; N $20.90 \%$.

3,3'-Bis[bis(carboxymethyl)amino]azobenzene (V): A solution of 3,3'-diaminoazobenzene $^{18}(12.6 \mathrm{~g}, 59 \mathrm{mmol})$, bromoacetic acid $(66.1 \mathrm{~g}, 0.475 \mathrm{~mol})$, and potassium carbonate $(69 \mathrm{~g}, 0.5 \mathrm{~mol})$ in a mixture of $35 \%$ aqueous ethanol $(300 \mathrm{ml})$ was heated to reflux for $40 \mathrm{~h}$. The reaction mixture is diluted with water $(500 \mathrm{ml})$ and then acidified to $\mathrm{pH} 2$. The product was separated by filtration, washed with water and then methanol. Yield 75\%;

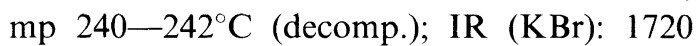
$(\mathrm{COOH}) \mathrm{cm}^{-1},{ }^{1} \mathrm{H}$ NMR (DMSO- $\left.d_{6}\right), \delta: 4.2$ $\left(\mathrm{s}, 8 \mathrm{H}, \mathrm{CH}_{2}\right), 6.7-7.6(\mathrm{~m}, 8 \mathrm{H}, \mathrm{ArH}) 9.0-9.3$ $(4 \mathrm{H}, \mathrm{COOH}) \mathrm{ppm} ; \alpha_{\max }=325 \mathrm{~nm} ; \varepsilon=13700$ $1 \mathrm{~mol}^{-1} \mathrm{~cm}^{-1}$ (ethanol). Found: C, $54.33 \%$; $\mathrm{H}, 4.53 \% ; \mathrm{N}, 12.30 \%$. Calcd for $\mathrm{C}_{20} \mathrm{H}_{20} \mathrm{~N}_{4} \mathrm{O}_{8}$ : $\mathrm{C}, 54.05 \% ; \mathrm{H}, 4.50 \%$; N, $12.61 \%$.

3-Bis (carboxymethyl)amino-3'-( $N$-carboxymethyl- $N$-butylcarbamoylmethyl)aminoazobenzene (VI): DCC $(0.97 \mathrm{~g}, 4.7 \mathrm{mmol})$ was added to a DMF-solution $(100 \mathrm{ml})$ of $\mathrm{V}(2.1 \mathrm{~g}$, $4.7 \mathrm{mmol}$ ) in an ice bath. The reaction mixture was stirred in an ice bath for $3 \mathrm{~h}$, and additionally stirred at room temperature overnight. Insoluble DCC-urea was filtered off. To the filtrate, butylamine $(2 \mathrm{ml}, 20 \mathrm{mmol})$ was added. The reaction mixture was stirred at room temperature for $2 \mathrm{~h}$, and then at $50^{\circ} \mathrm{C}$ for 
$2 \mathrm{~h}$. The mixture was poured into water $(500 \mathrm{ml})$; the solution was basified to $\mathrm{pH} 10$, DCC-urea was then separated and unreacted butylamine was extracted with benzene. The product was precipitated into acid solution $(\mathrm{pH}$ 2 ), and then recrystallized from acetone. Yield $30 \%$; mp 195- $198^{\circ} \mathrm{C}$ (decomp); IR (KBr): $3260(\mathrm{NH}), 1700(\mathrm{COOH}) .1675$ (amide $\mathrm{C}=\mathrm{O}$ ), $1600\left(\mathrm{COO}^{-}\right) \mathrm{cm}^{-1} ;{ }^{1} \mathrm{H}$ NMR (DMSO$\left.d_{6}-\mathrm{CDCl}_{3}\right), \delta: 0.8\left(\mathrm{t}, 3 \mathrm{H}, \mathrm{CH}_{3}\right), 1.3(\mathrm{~m}, 4 \mathrm{H}$, $\left.\mathrm{CH}_{2}\right), 3.1\left(\mathrm{t}, 2 \mathrm{H}, \mathrm{N}-\mathrm{CH}_{2}\right), 4.2(\mathrm{~s}, 8 \mathrm{H}$, $\left.\mathrm{N}-\mathrm{CH}_{2}-\mathrm{COO}\right), 6.7$ (s, 2H, 4-, 4'-ArH), 7.0 (s, 2H, 5-, 5'-ArH), 7.3 (m, 3H, NH, 2-, 2'-ArH), $8.0\left(\mathrm{~s}, 2 \mathrm{H}, 6-, 6^{\prime}-\mathrm{ArH}\right), 9.6-10.5(3 \mathrm{H}, \mathrm{COOH})$ ppm; $\alpha_{\max }=323 \mathrm{~nm} ; \quad \varepsilon=132001 \mathrm{~mol}^{-1} \mathrm{~cm}^{-1}$ (ethanol). Found: C, 57.58\%; H, 5.92\%; N, $13.92 \%$. Calcd for $\mathrm{C}_{24} \mathrm{H}_{29} \mathrm{~N}_{5} \mathrm{O}_{7}: \mathrm{C}, 57.72 \%$; $\mathrm{H}, 5.81 \%$; N $14.03 \%$.

3, $3^{\prime}$-Bis $(N$-carboxymethyl- $N$-butylcarbamoylmethyl)aminoazobenzene (VII): Dianhydride of $\mathrm{V}$ was synthesized with $p$-toluenesulfonyl chlolide (TosCl). ${ }^{19}$ Thus, TosCl $(0.7 \mathrm{~g}$, $3.7 \mathrm{mmol})$ was added to a solution of $\mathrm{V}(1.7 \mathrm{~g}$, $3.5 \mathrm{mmol})$ and triethylamine $(2.2 \mathrm{ml}, 14.7$ mmol) in anhydrous pyridine $(35 \mathrm{ml})$. The reaction mixture was stirred at room temperature for $15 \mathrm{~min}$ and at $70^{\circ} \mathrm{C}$ for $15 \mathrm{~min}$, and then cooled to room temperature. The remaining $\mathrm{Tos} C l(0.7 \mathrm{~g})$ was added to the cooled reaction mixture. The mixture was stirred at room temperature for $1 \mathrm{~h}$ and at $70^{\circ} \mathrm{C}$ for $1.5 \mathrm{~h}$, and then concentrated under reduced pressure; the oily residue was thoroughly washed with hexane, and dissolved in alcohol free chloroform $(150 \mathrm{ml})$. The solution was cooled at $-15^{\circ} \mathrm{C}$ overnight; insoluble triethylammonium $p$-toluenesulfonate and triethylammonium chloride was separated by filtration. The filtrate was washed with water, dried over anhydrous sodium sulfate, and then concentrated under reduced pressure. The residue was recrystallized from chloroformhexane $(1: 2), \mathrm{mp} 143-145^{\circ} \mathrm{C}$ (decomp.). To the solution of dianhydride $(0.2 \mathrm{~g})$ in anhydrous THF $(20 \mathrm{ml})$, butylamine $(1 \mathrm{ml})$ was added; the reaction mixture was stirred at room tempera- ture overnight, refluxed for $30 \mathrm{~min}$ and then poured into water $(100 \mathrm{ml})$. The aqueous solution was extracted with ether, acidified to $\mathrm{pH}$ 2.5. The product thus precipitated was filtered, washed with water. Yield $63 \% ; \mathrm{mp}$ $203-206^{\circ} \mathrm{C}$ (decomp.); $\alpha_{\max }=322 \mathrm{~nm}, \quad \varepsilon=$ $148001 \mathrm{~mol}^{-1} \mathrm{~cm}^{-1}$ (ethanol). Found: C, $60.90 \% ; \mathrm{H}, 6.97 \%$; N, $14.96 \%$. Calcd for $\mathrm{C}_{28} \mathrm{H}_{38} \mathrm{~N}_{6} \mathrm{O}_{6}: \mathrm{C}, 60.69 \% ; \mathrm{H}, 6.88 \% ; \mathrm{N}$, $15.16 \%$.

3,3'-Bis[bis(carboxymethyl)-aminomethyl]azobenzene (IIX): 3,3'-Bis(hydroxymethyl)azobenzene, ${ }^{17 \mathrm{c}}$ prepared by reductive coupling from $m$-nitrobenzylalcohol, was converted to $3,3^{\prime}$-bischloromethylazobenzene by treatment of thionyl chloride, $\mathrm{mp} 102-104^{\circ} \mathrm{C}$. A mixture of iminodiacetic acid $(14 \mathrm{~g}, 0.105 \mathrm{~mol})$ and potassium carbonate $(12.5 \mathrm{~g})$ in water $(200 \mathrm{ml})$ was added to the solution of $3,3^{\prime}$ bischloromethylazobenzene $(5 \mathrm{~g}, 18 \mathrm{mmol})$ in ethanol $(150 \mathrm{ml})$. The reaction mixture was heated to reflux for $24 \mathrm{~h}$ with stirring, and then acidified to $\mathrm{pH} 2.5$. The solid thus formed was separated, then dissolved in an alkali solution ( $\mathrm{pH}$ 9). Insoluble portion was filtered off and the filtrate was acidified to $\mathrm{pH} 2.5$. The resulting orange solid was separated, washed with water. Yield $40 \%$; mp $210-212^{\circ} \mathrm{C}$; IR (KBr): $1710(\mathrm{COOH}), 1610\left(\mathrm{COO}^{-}\right) \mathrm{cm}^{-1} ;{ }^{1} \mathrm{H}$ NMR (DMSO- $\left.d_{6}\right), \delta: 3.6\left(\mathrm{~s}, 8 \mathrm{H}, \mathrm{N}-\mathrm{CH}_{2} \mathrm{COO}\right)$, $4.1\left(\mathrm{~s}, 4 \mathrm{H}, \mathrm{CH}_{2}-\mathrm{N}\right), 7.7$ (d, 4H, 4-, 5-ArH), 8.0 (d, 4H, 2-, 6-ArH) ppm; $\alpha_{\max }=320 \mathrm{nm;}$ $\varepsilon=157001 \mathrm{~mol}^{-1} \mathrm{~cm}^{-1}$ (ethanol). Found: C, $55.38 \% ; \mathrm{H}, 5.31 \% ; \mathrm{N}, 12.01 \%$. Calcd for $\mathrm{C}_{22} \mathrm{H}_{24} \mathrm{~N}_{4} \mathrm{O}_{8}: \mathrm{C}, \quad 55.93 \% ; \mathrm{H}, 5.08 \% ; \mathrm{N}$, $11.86 \%$.

\section{Synthesis of Vinyl Monomers}

3-Hydroxy-3'-carboxy-5'-acrylamidoazobenzene: A solution of $m$-nitrosophenol $(1.1 \mathrm{~g}$, $9 \mathrm{mmol})$ in DMAc $(10 \mathrm{ml})$ was added to a solution of 3,5-diaminobenzoic acid $(1.52 \mathrm{~g}$, $10 \mathrm{mmol})$ in DMAc $(10 \mathrm{ml})$ at room temperature under nitrogen gas stream. The reaction mixture was stored at dark for 3 days, heated at $50^{\circ} \mathrm{C}$ for $30 \mathrm{~min}$, and then poured into ethyl 
acetate (AcOEt $100 \mathrm{ml}$ ). Insoluble black precipitate was filtered off; the filtrate was washed with water and then dried over anhydrous sodium sulfate. To the AcOEt solution were added a trace of hydroquinone, $N, N$-dimethylaniline $(1.25 \mathrm{ml})$, and the solution of acryl chloride $(0.8 \mathrm{ml}, 10 \mathrm{mmol})$ in AcOEt $(10 \mathrm{ml})$. The reaction mixture was stirred in an ice bath, allowed to stand overnight. Insoluble solid was filtered off; the filtrate was washed with dil. hydrochloric acid solution, dried over anhydrous sodium sulfate, and then concentrated under reduced pressure. The oily residue was purified by column chromatography (Wako gel $\mathrm{C}-300$ ). Yield $10 \% ; \mathrm{mp}$ $230-233^{\circ} \mathrm{C}$ (decomp.); IR (KBr): $3230(\mathrm{OH}$, $\mathrm{NH}), 1695(\mathrm{COOH}), 1675$ (amide $\mathrm{C}=\mathrm{O}$ ) $\mathrm{cm}^{-1}$; $1 \mathrm{H}$ NMR (dimethyl sulfoxide, DMSO- $d_{6}$ ), $\delta$ : $5.7\left(\mathrm{q}, 1 \mathrm{H},=\mathrm{CH}_{2}\right), 6.3\left(\mathrm{~m}, 2 \mathrm{H},-\mathrm{CH}=\mathrm{CH}_{2}\right)$, 7.0 (s, 1H, 4-ArH), 7.3 (s, 3H, 2-, 4'-, 6'-ArH), 8.1 (s, 1H, 6-ArH), 8.2 (s, 1H, 2'-ArH), 9.4-9.7 $(1 \mathrm{H}, \mathrm{OH}), 10.3-10.7(1 \mathrm{H}, \mathrm{COOH}) \mathrm{ppm}$; $\alpha_{\max }=314 \mathrm{~nm} ; \quad \varepsilon=190001 \mathrm{~mol}^{-1} \mathrm{~cm}^{-1}$ (ethanol). Found: C,61.74\%; H, 4.72\%; N, 12.95\%. Calcd for $\mathrm{C}_{16} \mathrm{H}_{13} \mathrm{~N}_{3} \mathrm{O}_{4}: \mathrm{C}, 61.74 \% ; \mathrm{H}, 4.18 \%$; $\mathrm{N}, 13.50 \%$.

3-Bis(carboxymethyl)amino-3'-[N-carboxymethyl- $N$-(4-vinylphenylcarbamoylmethyl)amino]azobenzene was synthesized with $\mathrm{V}$ and 4-aminostyrene by a similar method to that of VI. Yield $23 \%$; mp $198^{\circ} \mathrm{C}$ (decomp.); IR (KBr): $3260(\mathrm{NH}), 2500-2800,1710(\mathrm{COOH}), 1670$ (amide $\mathrm{C}=\mathrm{O}), 1610\left(\mathrm{COO}^{-}\right) \mathrm{cm}^{-1} ;{ }^{1} \mathrm{H} \mathrm{NMR}$ $\left(\mathrm{DMSO}-d_{6}\right) ; \delta: 4.3\left(\mathrm{~s}, 8 \mathrm{H}, \mathrm{CH}_{2}\right), 5.1(\mathrm{~d}, 1 \mathrm{H}$, $\left.=\mathrm{CH}_{2}\right), 5.6\left(\mathrm{~d}, 1 \mathrm{H},=\mathrm{CH}_{2}\right), 6.4(\mathrm{t}, 1 \mathrm{H}$, $-\mathrm{CH}=), 6.7-8.0(\mathrm{~m}, 12 \mathrm{H}, \mathrm{ArH}) ; \alpha_{\max }=$ $323 \mathrm{~nm} ; \quad \varepsilon=132001 \mathrm{~mol}^{-1} \mathrm{~cm}^{-1} \quad$ (ethanol). Found: C, 61.29\%; H, 5.46\%; N, 13.29\%. Calcd for $\mathrm{C}_{28} \mathrm{H}_{27} \mathrm{~N}_{5} \mathrm{O}_{7}$ : C, $61.65 \%$; H, $4.95 \%$; N, $12.84 \%$.

3-Bis(carboxymethyl)aminomethyl- $3^{\prime}-[N-$ carboxymethyl- $N$-(4-vinylphenylcarbamoylmethyl)aminomethyl]azobenzene: Yield $28 \%$; mp $91-93^{\circ} \mathrm{C} ; \alpha_{\max }=320 \mathrm{~nm} ; \varepsilon=170001 \mathrm{~mol}^{-1}$ $\mathrm{cm}^{-1}$ (ethanol). Found: C, 62.51\%; H, 6.09\%; $\mathrm{N}, 11.85 \%$. Calcd for $\mathrm{C}_{30} \mathrm{H}_{31} \mathrm{~N}_{5} \mathrm{O}_{7}: \mathrm{C}, 62.83 \%$;
$\mathrm{H}, 5.41 \% ; \mathrm{N}, 12.22 \%$.

\section{Polymerization}

Copoly-I: A $10 \mathrm{ml}$ polymerization tube was charged with 3-hydroxy-3'-carboxy-5'-acrylamidoazobenzene $(0.07 \mathrm{~g}, 0.2 \mathrm{mmol})$, styrene $(0.84 \mathrm{~g}, 8 \mathrm{mmol})$, AIBN $(0.02 \mathrm{~g})$, and dioxane $(5 \mathrm{ml})$. The tube was degassed by three freeze-thaw cycles and sealed at $0.5 \mathrm{mmHg}$. The polymerization was carried out at $60^{\circ} \mathrm{C}$ for $72 \mathrm{~h}$; the solution was then poured into vigorously stirred methanol $(100 \mathrm{ml})$. The suspension was filtered, the solid polymer was washed with methanol. Yield 70\%; Amount of pendant azobenzene unit: $7.0 \%$ (calcd from an absorbance at $323 \mathrm{~nm}) ;[\eta]=0.15 \mathrm{dl} \mathrm{g}^{-1}, 0.2 \%$ DMF solution at $25^{\circ} \mathrm{C}$.

Copoly-II: Yield 57\%; Azobenzene unit $6.9 \% ;[\eta]=0.15 \mathrm{dl} \mathrm{g}^{-1}$.

Copoly-III: Yield 54\%; Azobenzene unit $4.5 \% ;[\eta]=0.13 \mathrm{dl} \mathrm{g}^{-1}$.

\section{Photo- and Thermal-Isomerization}

An aqueous solution of azobenzene derivative $\left(1.25 \times 10^{-4} \mathrm{M}^{-1}\right)$ containing 1.2 equivalent of sodium hydroxide was irradiated at $25^{\circ} \mathrm{C}$ by using a $75 \mathrm{~W}$-high pressure $\mathrm{Hg}$ lamp with UV-cut filter (Toshiba UV-31).

The rate constants were calculated by monitoring the absorption maxima of transisomer ( $A_{\text {trans }}, \pi-\pi^{*}$ band) against times. The first order plots were generally linear for a half-period to reach a stationary state. The degree of isomerization was calculated on the assumption that the absorption maximum of the cis-isomer at $\pi-\pi^{*}$ band would be negligible ${ }^{4 a, 8,20}$ and its absorbance $\left(A_{\text {cis }}\right)$ would be that on the straight line joining two isosbestic points: $c i s \%=\left(A_{\text {trans }}-A_{t}\right) /\left(A_{\text {trans }}-A_{\text {cis }}\right)$, where $A_{t}$ indicates the absorbance at $\pi-\pi^{*}$ band of the isomerized product.

\section{Metal Extracting Efficiency of Polymers}

To $5 \mathrm{ml}$ of the benzene solution of polymer (concentration of azobenzene unit, $10^{-3} \mathrm{Ml}^{-1}$ ) was added $5 \mathrm{ml}$ of an aqueous picric acid so- 
lution $\left(10^{-3} \mathrm{Ml}^{-1}\right)$ containing metal hydroxide $\left(2.5 \times 10^{-3} \mathrm{Ml}^{-1}\right)$. After vigorous stirring for $30 \mathrm{~min}$, an insoluble metal complexed polymer was separated by centrifigation. The concentration of picrate ion in the aqueous phase was determined spectophotometrically: in water, picrate salt has $\alpha_{\max }$ at $355 \mathrm{~nm}$ $\left(\varepsilon=144001 \mathrm{~mol}^{-1} \mathrm{~cm}^{-1}\right)$.

\section{REFERENCES}

1. For a review, G. S. Kumar and D. C. Neckers, Chem. Rev., 89, 1915 (1989).

2. M. Blank, L. M. Soo, N. H. Wassermann, and B. F. Erlanger, Science, 214, 70 (1981).

3. S. Shinkai, S. Nakamura, M. Nakashima, U. Manabe, and M. Iwamoto, Bull. Chem. Soc. Jpn., 58, 2340 (1985).

4. a) S. Shinkai, T. Nakaji, T. Ogawa, M. Shimokawa, and O. Manabe, J. Am. Chem. Soc., 103, 111 (1981); b) ibid., 105, 1851 (1983); c) S. Shinkai, K. Shigematsu, Y. Honda, and O. Manabe, Bull. Chem. Soc Jpn., 57, 2879 (1984); d) ibid., 60, 1819 (1987).

5. W. R. Brode, J. H. Gould, and G. M. Wyman, J. Am. Chem. Soc., 74, 4641 (1952).

6. N. E. Briffet, F. Hibbert, and R. J. Sellens, J. Am. Chem. Soc., 107, 6712 (1985).
7. J. J. Delang, J. M. Robertson, and I. Woodward, Proc. R. Soc. London, Sec. A, 171, 398 (1939).

8. D. S. Frohlinde, Ann., 612, 131 (1957).

9. S. Shinkai, T. Kouno, Y. Kusano, and O. Manabe, J. Chem. Soc. Perkin Trans 1, 2741 (1982).

10. G. Anderegg, Helv. Chim. Acta, 47, 1801 (1964).

11. I. O. Sutherland, Ed., "Comprehensive Organic Chemistry II," Pergamon Press, Oxford, 1979.

12. A. Ringbon "Complexation in Analytical Chemistry," John Wiley and Sons Inc., New York, N.Y., 1963.

13. M. Shirai, A. Ueda, and A. Tanaka, Makromol. Chem., 186, 493 (1985).

14. R. D. Hancock and A. E. Martell, Chem. Rev., 89, 1875 (1989).

15. S. R. Adams, J. P. Y. Kao, G. Grynkiewicz, A. Minta, and R. Y. Tsien, J. Am. Chem. Soc., 110, 3212 (1988).

16. L. Alfonso and D. N. Kravtsov, Dokl. Akad. Nauk SSSR, 179, 333 (1968), Chem. Abstr., 69, 67039c (1968).

17. "Beilstein Handbuch XVI," a) p 233, b) p 209, c) p 144 (1933).

18. P. Ruggli and M. Hinovker, Helv. Chim. Acta, 17, 396 (1934); Chem. Abstr., 28, 3589 (1934).

19. S. R. Sandler and W. Karo, "Organic Functional Group Preparation III" Academic Press, New York, N.Y., 1972.

20. H. Rau and E. Luddecke, J. Am. Chem. Soc., 104, 1616 (1982). 